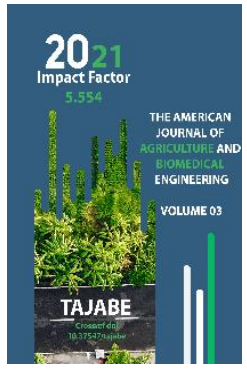

Journal Website: http://theamericanjour nals.com/index.php/taj abe

Copyright: Original content from this work may be used under the terms of the creative commons attributes 4.0 licence.

\section{Research On The Application Of Protein Soya Is From Local Raw Materials From Uzbekistan}

To'xtayev Shuxrat

Tashkent Chemical-Technological Institute, Tashkent, Uzbekistan

Ahrarov Umid Bakievich

Tashkent Chemical-Technological Institute, Tashkent, Uzbekistan

Akramova Ra'no Ramizitdinovna

Tashkent Chemical-Technological Institute, Tashkent, Uzbekistan

Choriyev Abdusattor Jo'raevich

Tashkent Chemical-Technological Institute, Tashkent, Uzbekistan

\title{
ABSTRACT
}

The object of research is the development of compound feed recipes from local oilseeds grown in Uzbekistan. The aim of this study is to introduce a recipe for the rational use of food purposes rich in proteins from local raw materials, as well as to study the physicochemical composition of acclimatized soybeans to increase the protein.

\section{KEYWORDS}

Soybean, raw material, composition, isoflavones, soybean protein, soybean product, soy isolates, soybean lecithin, soybean flour, soybean milk.

\section{INTRODUCTION}

The industry produces three types of soy protein products; skim flour (contains about $50 \%$ protein), concentrates (70-75\% protein) and isolators (90-99\% protein). In addition to their high biological value, soy proteins have a variety of functional properties that facilitate their culinary use.

Soy protein in any of three forms can be textured, structured; it has a high swelling capacity, moisture-absorbing and fat-binding capacity, retains its shape during heat treatment and has a texture and consistency characteristic of meat products.

Soy protein products are used to enrich vegetables and cereals, as well as sweet dishes, baked goods and, in addition, as a substitute for meat and fish. So, for example, the introduction of $3 \%$ fat-free soy flour into 
the recipe for minced meat and fish products reduces the filling of the main raw material by $7-10 \%$.

If it is necessary to exclude cow's milk from the diet, it is replaced in the corresponding formulations with soy milk. To prepare the latter, soy flour is poured with cold water (1: 10), stirred thoroughly, heated to $60^{\circ} \mathrm{C}$ and kept at this temperature for 1 hour, stirring occasionally, then filtered through a linen cloth.

Finished soy milk contains about $5 \%$ solids: 3 $4 \%$ protein, $0.5 \%$ fat, $0.2 \%$ ash. Soy milk can be used in traditional recipes (semolina pudding, milk jelly, vanilla cream, etc.) instead of cow milk (soy flour is added to the mousse).

On the basis of soy milk, protein cocktails with various natural juices or fruit and berry syrups can be prepared. Ready-made sweet dishes have good organoleptic characteristics and are not inferior in biological value to similar products with cow's milk (see Table 100).

Fish cakes with soy protein products (diets No. 2, No. 3, No. 5, No. 6, No. 8, No. 9, No. 10s, No. 11, No. 15). Fish fillets (hake, cod and other types of skinny ocean fish) are minced in a meat grinder (hole diameter is $3 \mathrm{~mm}$ ), combined with wheat bread soaked in milk, and re-grinded in a meat grinder.

Salt and soy flour (or soy protein isolate) are added to the mass and kneaded in a meat mixer for 5-7 minutes. Cutlets are formed, steamed, or breaded in breadcrumbs, fried in a pan on both sides until a crust forms, and then in an oven at $250-280^{\circ} \mathrm{C}$ for 5 minutes (see Table 100).
Stuffed fish with soy protein products (for all diets except No. 4). Soy flour or soy protein isolate is introduced into the fish cutlet mass, kneaded for 7-8 minutes in a meat mixer. Loaves are formed and boiled for 30-40 minutes (see "Dishes with milk-protein products", see Table 100).

Fish soufflé with soy protein products (for all diets, except for No. 4). Prepared soufflé of fish (hake, cod) is boiled in water until cooked, cooled to room temperature and chopped, passing through a meat grinder (hole diameter - $3 \mathrm{~mm}$ ), combined with prepared thick milk sauce and re-chopped (using a meat grinder); add softened butter, egg yolk, salt, mix in an electric whipping machine (540 rpm) for 3-4 minutes.

Add whipped soy and egg whites (soy flour or soy protein isolate is pre-soaked in water in a ratio of 2: 1 for 30 minutes at $40^{\circ} \mathrm{C}$, add chicken protein and beat in an electric mixer for 3 minutes), gently mix, put in greased form butter and steamed for 25 minutes.

\section{Composition and medicinal properties of soy products}

Soybeans contain approximately $35 \%$ protein, $9 \%$ carbohydrates, $17 \%$ fat. The digestibility of soy is approximately $91 \%$. The digestibility of soy proteins is $77-92 \%$, fats - $94-99 \%$, carbohydrates - about $80 \%$.

Soy proteins are distinguished by a unique amino acid composition, which is practically not inferior to proteins of animal origin (Table 20.1), as noted in a series of documents (WHO, 1985, 1989). The missing amino acids in soy, as in other legumes, are sulfur-containing methionine and cysteine. However, soybeans 
have high enough levels of these amino acids to meet the amino acid requirements of the human body while adhering to the recommended intake of soybeans.

Whole soybean seeds contain $9.5 \%$ albumin and $75.8 \%$ globulin; the albumin content in soybean embryos is even higher (17.3\%). Most of the proteins exist as storage proteins (7Sconglycinin and 11S-glycinin), the rest are represented by internal enzymes (lipoxygenase, urease, amylase, etc.), hemagglutinins, protein inhibitors and membrane lipoproteases.

Table 20.1 Comparison of the chemical composition of soybeans and beef

\begin{tabular}{|c|c|c|}
\hline Indicator (per $100 \mathrm{~g}$ of product) & Soy & Beef \\
\hline Protein $(\mathrm{g} \%)$ & 34,9 & 20,0 \\
\hline Amino acids: & 34,36 & 19,9 \\
\hline irreplaceable & 21,69 & 12,24 \\
\hline replaceable & 12,67 & 7,7 \\
\hline \multicolumn{3}{|l|}{ Vitamins (mg\%): } \\
\hline$E$ & 17,3 & -- \\
\hline $\mathrm{B}_{6}$ & 0,85 & 0,39 \\
\hline biotin & 0,06 & 0,003 \\
\hline thiamine & 0,94 & 0,07 \\
\hline \multicolumn{3}{|l|}{ Minerals (mg\%) } \\
\hline potassium & 1607 & 305 \\
\hline calcium & 348 & 10,2 \\
\hline magnesium & 226 & 22 \\
\hline phosphorus & 603 & 188 \\
\hline iron & 9,67 & 2,9 \\
\hline
\end{tabular}


Isoflavones are a unique component of soy proteins that largely determines their therapeutic efficacy.

Isoflavones are diphenolic compounds that are easily extractable with alcohol. They have a weakly expressed estrogenic activity (phytoestrogens). They are extremely rare in nature, making soybeans a unique dietary source. There are three main isoflavones known: genistein (the most studied), daidzein, and glycitein. They are natural antioxidants. The largest number of works devoted to soy isoflavones is associated with their role in the prevention and treatment of cardiovascular diseases, malignant tumors, climacteric conditions.

Soybean oil, a valuable source of vegetable fat, has a unique chemical composition and biological effect on the human body. Soy contains high concentrations of essential nutrients - polyunsaturated fatty acids, including linolenic, which is poorly represented in other sources (Table 20.2).

Table 20.2

\section{Chemical composition of soy and other types of vegetable oils}

(per $100 \mathrm{~g}$ of product)

\begin{tabular}{|c|c|c|c|}
\hline Fatty acid & Soybean oil & Sunflower oil & Olive oil \\
\hline $\begin{array}{c}\text { Total saturated fatty acids } \\
\text { (g), including: }\end{array}$ & 99,9 & 99,9 & 99,8 \\
palmitic & 13,9 & 11,3 & 15,75 \\
stearic & 10,3 & 6,2 & 12,9 \\
Monounsaturated fatty acids \\
(g):
\end{tabular}




\begin{tabular}{|l|c|c|c|}
\hline Tocopherols (mg) & 10,3 & - & Traces \\
& 114,0 & 67,0 & 13,0 \\
\hline
\end{tabular}

The high content of phospholipids (lecithin) in soybeans makes it possible to use it in the production of phosphatide concentrates used to increase the biological value of food products, as well as an independent medicinal product. The chemical structure of phospholipids, their diphilicity, the presence of charged groups determine the uniqueness of their physiological properties. Polar lipids can be found in cells in all living organisms. However, for commercial use only sources that have high concentrations of phospholipids are of interest, and among them soy is the most important.

Phospholipids are highly specialized lipids and are fundamental components of cell membranes and membranes of structural elements of cells. By introducing phospholipids, it is possible to correct the cellular functions associated with membrane proteins. Phospholipids - important components of lipoproteins, surfactants and bile, take part in the work of the nervous system, in the process of blood clotting, and affect the concentration of cholesterol in the blood.

Soy dietary fiber with a low fat and sodium content has the highest healing properties in patients with intestinal pathology, metabolic disorders, digestive disorders, atherosclerosis, and many other diseases. Soybean dietary fiber contains both soluble and insoluble dietary fiber, has a low energy value $(0.5-0.7 \mathrm{kcal} / \mathrm{g})$, and high sorption properties.

Additionally, it should be noted that soybean seeds are rich in B vitamins and fat-soluble vitamins $\mathrm{D}, \mathrm{E}, \mathrm{K}$, a number of important microelements (potassium, magnesium, etc.). They contain a sufficient amount of phytic acid, which affects the exchange of zinc and copper.

Note that the nutritional value of legume proteins, including soybeans, is greatly reduced by natural biologically active antialimentary substances: proteinase inhibitors, phytohemagglutinins, goitrogens, etc. Thus, proteinase inhibitors have the ability to significantly reduce the catalytic activity of proteolytic enzymes of the gastrointestinal tract of animal organisms, forming inactive complexes with them. The intake of these anti-alimentary factors in the body leads to a decrease in the hydrolysis of food proteins, a decrease in the efficiency of their assimilation and, as a consequence, hypertrophy of the pancreas, impaired liver function, growth retardation, etc. The high content of proteinase inhibitors significantly reduces the nutritional value of legume proteins.

However, the content of protease inhibitors in the processed soybean seeds is significantly reduced in comparison with untreated seeds. The use of modern soybean processing technologies (production of concentrates, isolates and texturates) makes it possible to obtain food products with a low content of 
anti-nutritional substances, which can be included in the diet as a source of high-quality protein.

\section{Soy products}

Before the introduction of dry composite mixtures into clinical practice, a variety of soybased products were used for many years in the nutrition of healthy and sick people: soy flour and soy milk, as well as fermented milk products made on its basis. Currently, soy products are widely represented on the world market: oil, flour, isolated protein, textured protein, soy protein concentrate, fermented soy products (soy sauce, miso, natto), food soy base (soy milk), soy food mass ( pasta, okara), lecithin.

In the letter of the Ministry of Health of the Russian Federation No. 1100 / 172-98-115 of January 28, 1998 "On the use of food from soybeans", the Department of State Sanitary and Epidemiological Supervision explained the main types of protein-containing products of soybean processing. Such products are obtained using two fundamentally different technologies:

1. The first of them is based on the method of pressing whole soybeans on the "soy cow" installation in order to obtain soy milk and its further processing products ("Tofu" cottage cheese, fermented milk products, drinks with flavors).

2. The second technology is intended for obtaining soy flour, soy protein concentrates and its textured forms, as well as soy protein isolates from defatted soybean meal.
As a rule, the products obtained according to the first technology and textured forms are used directly in the nutrition of the population, while non-textured soy flour, concentrates and soy protein isolates are semi-finished products widely used in the formulations of various types of industrial food products. The production of soy protein products and semi-finished products, as well as food products with their inclusion, must be carried out in accordance with the technical documentation agreed in accordance with the established procedure with the Department of State Sanitary and Epidemiological Supervision of the Ministry of Health of Russia.

Soy-based products have a high biological value and are often superior in this parameter to similar products of animal origin (Table 20.3).

Soy flour (contains $50 \%$ protein by dry weight) is a technologically simple product suitable for the production of a variety of culinary products. But, despite the complex of positive characteristics, soy flour products have some taste characteristics that limit their use, have a limited shelf life. In addition, soy flour has a high content of protease inhibitors (it is slightly reduced when it is autoclaved).

Soy milk is a complete replacement for natural milk. It is used for lactase deficiency, allergy to milk proteins, etc. On the basis of soy milk, fermented milk soy products are produced, which allow you to additionally enrich the diet with high-quality protein. These include: kefirs and yoghurt, obtained on the basis of milk as a result of its fermentation with sourdough cultures; bean curd obtained by thermal 
precipitation fermented with lactic acid starter cultures; tofu cottage cheese, traditional for eastern countries, made from the original soy drink by precipitating dry substances with food acids, etc. Similar products are produced using various technologies by a number of Russian manufacturers (Inter-Soya, Belok, etc.). In parallel with such products as milk,
Okara, a food soybean fortifier, is produced, which is the non-extractable part of soybeans.

Soy concentrates have a higher protein content (up to $70 \%$ ).

Table 20.3

Chemical composition of protein-containing products (in $100 \mathrm{~g}$ )

\begin{tabular}{|c|c|c|c|c|c|}
\hline Indicator & $\begin{array}{l}\text { Soy } \\
\text { flour }\end{array}$ & $\begin{array}{c}\text { Soysemi-finished } \\
\text { products }\end{array}$ & Egg white & $\begin{array}{c}\text { Low-fat cottage } \\
\text { cheese }\end{array}$ & $\begin{array}{c}\text { Beef } \\
\text { I category }\end{array}$ \\
\hline Protein, $\mathrm{g}$ & 49 & 52 & 10,8 & 18,0 & 18,6 \\
\hline Fat, g & 8 & 2 & 0 & 0,6 & 14,0 \\
\hline Carbohydrates, g & 22 & 36 & 0,5 & 1,8 & 0 \\
\hline Cholesterol, g & 0 & 0 & 0 & 0,04 & 0,08 \\
\hline Cellulose, g & 3,5 & 3,5 & 0 & 0 & 0 \\
\hline \multicolumn{6}{|c|}{ Vitamins, mg } \\
\hline Beta carotene & 0,01 & 0,02 & 0 & 0 & 0 \\
\hline Vitamin A & 0,002 & 0,03 & 0 & 0,01 & 0 \\
\hline Vitamin E & 0,4 & 0,29 & 0 & 0 & 0,57 \\
\hline Thiamine $\left(B_{1}\right)$ & 0,32 & 0,9 & 0 & 0,04 & 0,06 \\
\hline Riboflavin $\left(B_{2}\right)$ & 0,31 & 0,29 & 0,56 & 0,25 & 0,15 \\
\hline Pyridoxine $\left(B_{6}\right)$ & 0,02 & 0,21 & 0,01 & 0,19 & 0,37 \\
\hline Niacin (PP) & 2,97 & 3,04 & 0 & 0,45 & 4,7 \\
\hline Choline & 225 & 251 & 0 & 0 & 70 \\
\hline
\end{tabular}


The American Journal of Agriculture and Boimedical Engineering (ISSN - 2689-1018)

IMPACT FACTOR

Published: June 30, 2021| Pages: 107-120

Doi: https://doi.org/10.37547/tajabe/Volume03Issueo6-15

2021: 5.554

OCLC - 1121105746

\begin{tabular}{|c|c|c|c|c|c|}
\hline \multicolumn{7}{|c|}{ Macro- andmicroelements, mg } \\
\hline Callium & 1800 & 1600 & 152 & 117 & 315 \\
\hline Sodium & 1,3 & 1,5 & 189 & 44 & 60 \\
\hline Calcium & 230 & 270 & 10,3 & 120 & 9 \\
\hline Phosphorus & 620 & 800 & 27 & 189 & 198 \\
\hline Magnesium & 330 & 230 & 9,2 & 24 & 31 \\
\hline Iron & 11,5 & 14,7 & 0,15 & 0,3 & 2,6 \\
\hline Copper & 0,68 & 0,68 & 0,051 & 0,06 & 0,18 \\
\hline Zinc & 3,2 & 3,5 & 0,231 & 0,364 & 3,2 \\
\hline
\end{tabular}

Currently, the main soybean processed product used in diet therapy is soyisolates (isolated proteins), which contain more than 90\% protein. Protein is obtained by careful chemical separation (extraction) of the protein component of the beans, passing through a series of technological steps. The resulting isolate is highly digestible and has a complete amino acid composition.

The digestibility of soy isolate is close to that of milk, beef and egg proteins. It is believed that products with PDCAAS $=1.0$ (amino acid coefficient of assimilation of proteins) are the most complete (Table 20.4). This includes soy isolate. It has been proven that the use of soy isolate as the sole source of protein allows you to fully maintain nitrogen balance in the body for a long time.

In addition to their high biological value, soy proteins have a variety of functional properties that facilitate their culinary use high swelling, moisture-absorbing and fatbinding capacity. Soy protein products are used to enrich vegetable and cereal dishes, flour products, sweet dishes, and also as a substitute for meat and fish. Thus, the introduction of $2 \%$ soy protein isolate into the formulation of minced meat and fish products reduces the filling of the main raw material by $7-10 \%$, but at the same time increases the biological value of the product.

Table 20.4 
The American Journal of Agriculture and Boimedical Engineering

\section{Assessment of the quality of some proteins according to the WHO (1989)}

\begin{tabular}{|c|c|c|c|}
\hline Protein source & PDCAAS & Protein source & PDCAAS \\
\hline Casein & 1,00 & Beans (canned) & 0,68 \\
\hline Egg white & 1,00 & Oats & 0,57 \\
\hline Soyisolate & 1,00 & Peanut & 0,52 \\
\hline Beef & 0,92 & Wheat & 0,40 \\
\hline
\end{tabular}

Soy isolates "Supro" are successfully used in the clinical practice of our department and a number of medical institutions (Research Institute of Nephrology, St. Petersburg State Medical University). Dry composite mixtures "Supro", in comparison with a number of others, differ in the minimum content of potentially hazardous contaminants and antialimentary substances. This allows researchers to recommend Supro proteins as the main source of nitrogen in various diets (Table 20.5). Soy isolates can be added to readymade food, baked goods (starch-soy bread), dairy products, sausages, etc. They are used as an independent product (when diluted with water) or by adding to cereals, soups, lactic acid products, baked goods, minced meat.

Soy isolate "Supro-760" is a powdery, hardly soluble substance. The product is $90 \%$ composed of highly digestible protein of high biological value. It is also important in the diet therapy of certain pathological conditions that the soy isolate "Supro-760" does not contain cholesterol, lactose and some other substances (for example, phosphorus).
"Supro-760" can be used dry as a food additive in dishes. It is used as a substitute for raw milk; for making dishes from vegetables; for the preparation of vegetable, meat, fish cutlets and pates. In clinical nutrition, Supro760 is especially indicated for conditions characterized by an increased need for proteins of high biological value, combined with a restriction of a number of nutrients (for example, with renal failure, when it is necessary to reduce the intake of phosphorus, potassium and sodium, some fat-soluble vitamins).

Soy isolates are used for the production of instant dry protein-vitamin-mineral complexes with high biological value. Along with isolated soy protein, their composition usually includes vitamin premixes, dietary fiber, carbohydrates, lecithin, lactulose, flavoring additives and other components that enhance the medicinal potential of the resulting drinks and their organoleptic properties.

Table 20.5 
The American Journal of Agriculture and Boimedical Engineering

I MPACT FACTOR (ISSN - 2689-1018)

Published: June 30, 2021| Pages: 107-120

Doi: https://doi.org/10.37547/tajabe/Volume03Issueo6-15

OCLC - 1121105746

The chemical composition of soy products most often used in preventive and therapeutic nutrition

\begin{tabular}{|c|c|c|}
\hline Chemicalcomposition & $\begin{array}{l}\text { "Supro-760" } \\
\text { ("Protein Technologies } \\
\text { International", Holland) }\end{array}$ & $\begin{array}{c}\text { "Diso" } \\
\text { ("Dietsoya", Russia) }\end{array}$ \\
\hline \multicolumn{3}{|l|}{ Content (\%): } \\
\hline proteins & 90 & 26 \\
\hline fat & 1 & 26 \\
\hline carbohydrates & 一 & 38 \\
\hline ash & 4,5 & 7 \\
\hline \multicolumn{3}{|l|}{ Vitamin content (per 100g): } \\
\hline$A(M E)$ & 一 & 3100 \\
\hline $\mathrm{D}(\mathrm{ME})$ & -- & 400 \\
\hline$E(M E)$ & - & -- \\
\hline$C(\mathrm{mg})$ & - & 8,6 \\
\hline thiamine (mg) & -- & 0,3 \\
\hline riboflavin (mg) & - & 1,2 \\
\hline niacinm (mg) & - & 0,7 \\
\hline pyridoxine (mg) & -- & 0,3 \\
\hline B 12 (mcg) & - & 3,5 \\
\hline pantothenic acid (mg) & - & 2,1 \\
\hline folicacid (mcg) & - & 40 \\
\hline $\begin{array}{c}\text { Mineral content (mg / per } \\
100 \mathrm{~g}):\end{array}$ & & \\
\hline
\end{tabular}




\begin{tabular}{|c|c|c|}
\hline calcium & - & 900 \\
\hline phosphorus & - & 800 \\
\hline magnesium & - & 80 \\
\hline iron & - & 8,4 \\
\hline zinc & - & 8,4 \\
\hline iodine (mcg) & - & 150 \\
\hline sodium & 130,0 & 500 \\
\hline potassium & 20,0 & -- \\
\hline
\end{tabular}

Composite mixtures include "Supro-2640", "Supro-651", "Supro-2725". ("Protein Technologies International"), "Diso", "Immunity", "Piquant", etc. ("Diet"), "Energy", "Grace" ("Research Institute of Health-improving Nutrition and New Technologies"), cocktails " Rouge "(" Rouge ") and a number of others.

The composite mixture "Supro-651" contains $80 \%$ protein, as well as calcium, phosphorus, sodium and potassium. It is also used as a substitute for cow's milk. The use of "Supro$651^{\prime \prime}$ is preferable in enhanced protein nutrition for individuals who do not have micronutrient restrictions.

"Supro plus-2640" is a fast-dissolving fine powder based on soy isolate, which has the same nutritional characteristics as dry whole milk, but at the same time contains an

additional amount of vitamins and microelements (vitamins A, D, iron, zinc, iodine). The amino acid composition of this product meets the requirements of the WHO
Requirements for Children and Adults, in WHO Technical Report Series No. 724, 1985; Recommended Food Intakes, Food and Nutrition Board, 10th edition; 1989 ). It can be used in a wide range of products where milk powder is traditionally used to enhance their bioavailability.

Of the manufacturers of soy products on the Russian market, the products of the Russian manufacturing company "Dietsoya" (Table 20.5) meet and comply with all dietary requirements, using ecologically safe and genetically not transformed, primarily domestic raw materials for the processing of soybeans. In Diso food systems, soy isolate forms the basis of products that are individually shown to patients with various pathologies. You should pay attention to one of the most important characteristics of the products of this company - high taste.

Soy lecithin ("Diso") is a complex mixture of neutral lipids (mainly triglycerides), polar lipids (phospho- and glycolipids) and carbohydrates. Soy lecithin is well tolerated and digestible. 
Phosphatidylcholine in soy lecithin is an essential structural component of cell membranes. In the presence of vitamin B5, phosphatidylcholine is converted into acetylcholine, one of the most important neurotransmitters for the brain. Lecithin is also a major component of the myelin sheaths of nerves and has a noticeable effect on the functioning of the central nervous system, without being a neurostimulant. Changes in phospholipid levels are associated with a deficiency of dopamine, a neurotransmitter that is almost absent in the brains of patients with Parkinson's disease. Taking lecithin for 35 months significantly improves the indicators of brain activity. Taking lecithin also contributes to remission of such a formidable disease as multiple sclerosis.

Lecithin is essential in the body to maintain normal cholesterol levels, the correct ratio of high-density lipoprotein (HDL) and low-density lipoprotein (LDL). According to the American Heart Association, regular consumption of 1-2 tablespoons of soy lecithin per day leads to a decrease in the manifestations of coronary and cerebral atherosclerosis and serves to prevent this pathology in people over 40-45 years old.

Its reception has a positive effect on cholesterol metabolism, the coagulation system, the condition of the skin and blood vessels. Lecithin activates the functions of the liver and pancreas, has a choleretic effect. The positive effect of soy lecithin on the immune system, physical activity, the activity of the endocrine glands, and on the processes of tissue recovery has been proven.
Indications for the appointment of soy lecithin are diverse: atherosclerosis, liver diseases, biliary and pancreatic systems, immunodeficiency and allergic conditions, during convalescence after diseases, operations, injuries. It is also used during periods of increased physical and mental stress. Also, lecithin relieves the symptoms of psoriasis and neurodermatitis, in which the antitoxic function of the liver and lipid metabolism are impaired. Therefore, it is used in the complex treatment of these systemic skin diseases. Lecithin is useful for treating nicotine addiction.

With a lack of a phospholipid complex in food, the process of assimilation of fat-soluble vitamins $A, E, D, K$ is disrupted, therefore lecithin is necessary even for practically healthy people with a meager diet.

It should be borne in mind that all commercial lecithins are not the same. Their composition and properties can vary depending on the source of production, the initial spectrum of their constituent phospholipids and the conditions for their production. In its composition, raw lecithins can contain up to $36 \%$ of crude soybean oil and only $64 \%$ of mixed phosphatides. In this case, the therapeutic and prophylactic efficacy of lecithin is determined by the content of phosphatidylcholine. In this regard, it should be noted soy lecithin produced by "Dietsoya", the content of the phospholipid complex in which is $96 \%$, and phosphatidylcholine $20-23 \%$.

Soy dietary fibers (which form the basis for the industrial production of soy bran and soy flakes "Diso", "Nuruflex", "Sovital", etc.) are successfully used in clinical practice and 
preventive medicine. The functional effect of the ballast substances contained in them is due to their physical properties: water absorption, swelling, sorption activity and high ion-exchange characteristics. They are used in all areas of the food industry to increase the fiber content of foods (bakery and confectionery products, breakfast mixes, diet foods, nutrition for athletes, etc.). Soy fibers normalize the motor activity of the gastrointestinal tract and are prebiotics. Soy bran has a higher concentration of ballast substances than those produced from other grains. In addition, the biological value of soy products is higher than similar cereals (Table 20.6).

Table 20.6

Nutritional Value of Soy Fiber Products Compared to Similar Cereal Products

\begin{tabular}{|c|c|c|c|c|c|}
\hline \multirow{2}{*}{ Composition per $100 \mathrm{~g}$} & \multirow{2}{*}{$\begin{array}{c}\text { Soy } \\
\text { flakes }\end{array}$} & Soy & \multicolumn{3}{|c|}{ Cereal flakes } \\
\cline { 4 - 6 } & bran & wheat & oat & rye \\
\hline Protein & $40 \%$ & $10,0 \%$ & $12,0 \%$ & $12,5 \%$ & $9 \%$ \\
\hline Fat & $22,5 \%$ & $2,0 \%$ & $2,0 \%$ & $7 \%$ & $2 \%$ \\
\hline Ballast substances & $25 \%$ & $64 \%$ & $71 \%$ & $68,5 \%$ & $62 \%$ \\
\hline Minerals & $5,5 \%$ & $3 \%$ & $0,5 \%$ & $2 \%$ & $2 \%$ \\
\hline Humidity & $8 \%$ & $8 \%$ & $13 \%$ & $10 \%$ & $13 \%$ \\
\hline
\end{tabular}

Soybean Meat is a product that combines the nutritional properties of soybeans with the taste of animal meat. Its cost is 2-3 times less than that of meat. From $100 \mathrm{~g}$ of dry semifinished product, $500 \mathrm{~g}$ of the finished product is obtained. Soy meat has a long shelf life without refrigeration and is quick to cook. Dry textured semi-finished products (produced by "Dietsoy", "Bona Vita", etc.) are popular in the

Russian market due to their high taste. Soy meat is produced using modern technology without adding chemical compounds under high pressure and temperature conditions.
The advantages of soy meat make it possible to recommend it for the nutrition of various groups of the population, including hospital patients, especially geriatric contingents, and the diet of schoolchildren and children attending kindergartens (recommended by the St. Petersburg Social Nutrition Department).

Attention should be paid to an important feature of the initial chemical composition of soy bran, which does not make it possible to widely use them in diet therapy - a high content of coarse dietary fiber, oligosaccharides (stachyose and raffinose), which contribute to flatulence, the 
phenomena of intestinal fermentative dyspepsia. The industrial production of soy bran and flakes undergoes a complex multistage process of extrusion, which provides a lightening of the chemical composition of the product and an increase in its nutritional therapeutic and prophylactic properties.

If we talk about the values or norms of consumption of soy protein products, then according to the Institute of Nutrition of the Russian Academy of Medical Sciences, there are no such recommendations. At the same time, in the USA, in organized groups (army, schools, etc.), these products are regularly used in food with an average frequency of at least once a day.

\section{REFERENCES}

1. Akhrarov $\mathrm{U}$, B. Taom tayerlash tekhnologasi.- T .: Shark. 2008.- 368 p.

2. Akhrarov U.B. Umidova M.Sh., Akhrarov Sh.U. "Ovqatlanish mahsulotlarini tayyorlash tekhnologasi." $\mathrm{T}$.: Yangi nashr. - 2017 - 520 p.

3. Baranov. V. S. Technology of production of public catering products.- $M$.: Economy. 1991.- 334 p.

4. Borovikova L.A. and other Research of food products. - M .: Economics. 1980 335 p.

5. Breitburg A.M. Balanced diet. Moscow: Gostorgizdat. 1957 th - 150 P.

6. Collection of recipes for dishes and culinary products for public catering establishments. - M .: Economics. 1983.$718 \mathrm{p}$.
7. Collection of recipes for national dishes and culinary products of the peoples of Uzbekistan. - T .: Mennat. 1987 .-- 220 p.

8. Abramov, N.l. The use of soybeans in meat processing industry / N.I. Abramov, M.I. Radish // Perspectives production and processing of soybeans in the Amur region. - Blagove-schensk, 1998. - pp. 8081.

9. Anischenko, N.I. Prospects for using soy protein for food purposes / N.I. Anischenko. -Blagoveshchensk, 1998. P.75-79.

10. Balakay, G.T. Soybeans: ecology, agricultural technology, processing / G.T. Balakay, O.S. Bezuglova.-Rostov n / a: Phoenix, 2003.-160 p.

11. Balakay, G.T. Soybeans on irrigated lands / G.T. Balakay .- M., 1999.

12. Bassisty, V.P. Fundamentals of agricultural technology production in the Russian Far East / V.P. Bassty. Khabarovsk: Book. publishing house, 2000. -290 p.

13. Babich, A.A. Soybeans for feed / A.A. Babich. - M .: Kolos, 1974.-112 p. 